\title{
IN DEFENSE \\ OF CHARISMA
}





\section{IN DEFENSE \\ OF CHARISMA}

VINCENT W. LLOYD

Columbia University Press New York 


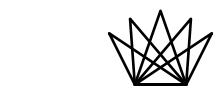

Columbia University Press

Publishers Since 1893

New York Chichester, West Sussex

cup.columbia.edu

Copyright (C) 2018 Columbia University Press

All rights reserved

Cataloging-in-Publication Data available from the

Library of Congress.

Names: Lloyd, Vincent W., I982- author.

Title: In defense of charisma / Vincent W. Lloyd.

Description: New York : Columbia University Press, [2018] |

Includes bibliographical references and index.

Identifiers: LCCN 2017039169 | ISBN 9780231183864

(cloth: acid-free paper) | ISBN 978023II8387I (pbk.) |

ISBN 9780231545204 (e-book)

Subjects: LCSH: Charisma (Personality trait) | Authority.

Classification: LCC BF698.35.C 45 L55 2018 | DDC $155.2 / 32-\mathrm{dc}_{23}$

$\mathrm{LC}$ record available at https://lccn.loc.gov/20I7039169

Columbia University Press books are printed on permanent and durable acid-free paper.

Printed in the United States of America

Cover design: Jordan Wannemacher 
For my daughter 
